\title{
Analysis of Garri Frying Machine Manufacturing in Nigeria: Design Innovation
}

\author{
Rufus Ogbuka Chime*,1, Odo Fidelis $\mathrm{O}^{2}$ \\ ${ }^{1}$ Mechanical Engineering, Institute of Management and Technology, 400001 Enugu Nigerian
}

${ }^{2}$ Food Tech, Institute of Management and Technology, 400001. Enugu, Nigeria

\author{
A R T I C L E I N F O \\ Article history: \\ Received: 14 August, 2018 \\ Accepted: 20 November, 2018 \\ Online: 07 December, 2018

\begin{tabular}{l}
\hline Keywords: \\
Design \\
Garri frying \\
Sustainability analysis \\
Environmental \\
Agriculture \\
Innovation and Manufacturing
\end{tabular}

\section{Introduction}

Garri which is creamy white grainy flour made from fermentation and gelatinization of which has faintly flavor, sour taste as a result of fermentation of new of new cassava tubers. It is consumed in Brazil and in most African countries especially in Nigeria where most of its preparations are done using local processing techniques. Researches into the mechanization method involved into the unit operations as peeling and washing of tubers, grating, dewatering, fermentation, sieving, frying, and cooling in garri production were done in the past years [1] Some machines were designed to help in the large scale [2-5]. Frying operation which is the unit operation that approves the value of the last product, in garri production. It was difficult to mechanize this operation perfectly and the processes was not well understood by many designers and manufacturers [6]. It was thought of by some people that garri frying means dehydration/roasting. The removal of water molecules or other liquids from solid to lessen the content or residual liquid to an acceptable value is otherwise known as

${ }^{*}$ Corresponding Author: Rufus Ogbuka Chime, Email: rumechservices@yahoo.com drying. The removal of some amount of water or other liquid from the solid material to reduce the substances or residual liquid to an acceptable low value is the means of solid drying [7]. The final step in a series of processing and handling operations and the goods from a dryer is often ready for final packaging. Drying is a relative term and methods of reduction moisture content from an initial value to some acceptable final value. Cassava has approximately $60 \%$ water content while final garri is between 10 15\% [8] Garri frying (called gratification), though a dehydrating process, is not a straightforward drying process. The moisture value of the cassava mash that was removed during sieving should be from $51-66 \%$ and should be $13 \%$ when the frying operation finishes. The product is allowed to dry from the bearest minimum of about $13 \%$ during the final operation known as frying operation. Recently, frying and drying machines are usually manufactured using stainless steel drum with rotary conveyor and paddles fixed along the conveyor to reduce rotation in the same axis of the drum. As mentioned earlier, traditionally, garri is fried by women in shallow earthenware of cast-iron pans (agbada) over a wood fire. 
The operator sits sideways by the fireplace while frying, and this brings discomfort due to heat and the sitting posture [9]

Many years ago, garri is fried by women in shallow earthen-ware cast-iron pans (agbada, Nigerian Ibo) over a wood fire. Female use spatula-like paddles of wood or calabash half sections to press the sieved mash against the hot surface of the frying pan, while continuously turning it to avoid cake production. The operator who sits beside the fire during frying process faces challenges base on the heat produced from the wood fire, inspired researchers.

In Nigeria for instance, quality mechanized garri processing plants are few, and as a result engineers and manufactures in Nigeria are seeking for improvement in already existing models. Model by definition unattainable in a given time/space but appends lastly. It is this endless pursuit that forms a justifiable process. Good system environments are necessary to the survival of humans and other organisms. Ways of minimizing human impact are environmentally-friendly chemical engineering, environmental resources management and environmental protection.

Report is obtained from green chemistry, earth science, environmental science, conservation biology and Ecological.

Economics studies the subjects of academic research that aim to address human economies and technological ecosystems [10].

Sustainability can be quite a malleable characterize.

Many people understand its purpose intuitively because it's hard to really pin down, it covers so many domains. The Brundtland Commission, made the best-known definitions of Environment and Development in The World Commission: Sustainable development is one that produce the needs of the people without bargaining the talent of future generations meeting their own needs sustainability manifests itself in industries at a variety of levels, including.

- Strategy -Some industries decide what to make as a resultof sustainable business ideals. Stony field Farms has made social and environmental responsibility a key part of its business strategy since it began. Supply chain \& value webs. Walmart requires its suppliers to evaluate and disclose the full impact of their goods. There continues to be demand attention to so-called company.

- Ecology, which evaluates the material and energy flows within whole industrial systems, often extending far beyond.

- Operations - The result of producing goods increasingly show ecological controls for floor casing industry Interface, the real justifiable business accomplishment was opening of the social and ecological effects of their processes because of problems, industries have inaugurated Environmental Management Systems (EMS), that have operationalized the tracking, documentation, and reporting of ecological certification, of ecological influences of the institution, There is a detailed of ISO standard (ISO 14001:2004) governing EMS. 5.

The level of sustainability concerns which is basically on product is where the majority of this guide will concentrate on, nevertheless it is obliging to hold onto the fact that sustainability is not the sphere of just single portion of the business. Truthfully, an actual produce of sustainability should be able to merely be existent surrounded by the framework of an ample comprehensive scheme that gives a backing to its affirmative influence societies, globe, as well as proceeds [11]. The procedure involved in making simpler a topic which is composite or constituent to minor portions acceptable to achieve an enhanced appreciation for that [12]. Innovation is well-defined merely for instance an idea that is recent, scheme, or process. Conversely, innovation is over and over again similarly observed as the use of improved way out that encounter novel necessities, tacit desires, otherwise prevailing market desires. The accomplishment comes via extra operational produces, procedures, facilities, know-hows, or business mockups that are readily obtainable towards the markets, governments as well as society. The term "innovation" is well-defined as unique something as well as additional operative also, consequently, first-hand, that "enters into" the market place or the general public. It is interrelated to, however, not the alike as, invention. [13]

\section{Literature Reviews}

In the past, tools and implements were developed to perform tasks that were made to complement human physical strength. The discovery of the wheel is probably the most revolutionizing optimization tool made by humans. In today's complex business and industrial environments, the solution of operational problems cannot be achieved by technological advances alone.

The multitude of options available for implementing an operational plan has mandated the development of systematic procedures for selecting the options that best benefit of the industries as a whole [13].

There are few automated garri processing plants in the Nigerian market which have found to be performing well as regards to the quality of garri. As the outcome, some new products (developments have been made by Nigerian researchers to solve the problems associated with the models already in the market.

\subsection{Traditional method}

Throughout garri frying processes, the moisture content concerted and most of the small lumps established are broken down by continuous pressing and agitation, heat is then increased in order to further cook and dehydrate the production. formerly, design on garri production plants did not get the required and acceptable cassava production for the consumers The researchers of those plants did not take into account the specifications of the existing local technology [14].

The UNIBADAN (University of Ibadan) upgraded garri fryer (Igbeka J. E.) is, made of a fireplace oven Incorporated with a chimney and a frying pan. The frying pan which is $200 \mathrm{~cm} \times 60 \mathrm{~cm}$ $x 10 \mathrm{~cm}$ is constructed to have trapezoidal shape with its side inclined at $60^{\circ}$ to the horizontal. The clination of the sides allows for gradual gravitational flow of garri down the sides of the fryer. It is made from a $4 \mathrm{~mm}$ thick black steel sheet, which is not easily corroded and does not turn black after heating [15]. 


\subsection{Mechanized methods}

\section{Newell Dunford model}

That equipment was a collaborative effort of Federal Institute of Industrial Research (FIIRO), Oshodi, Nigeria. and Newell Dunford Company, London. It is a garri processing plant of which the fryer has a unique component. In the frying units, heat generated in the gas fire is measured and regulated by thermostats at several points in the process.

\section{Brazilian model}

This equipment's, designed and constructed in Brazil, appears to be better than the Newell Dunford models and the product obtained from it is comparable to Nigeria garri, , even though it is not accurately the same. In this Design, frying was not distributed within a given batch and the process looked more like dried cassava mash than cooked and fried garri.

\section{Fabrico model}

This design which was constructed and manufactured by a Company, FABRICO, in Nigeria, produces an end-product. That is closer to one in the market(garri). The manufactured goods were not cooked but looked more like roasted garri. The University of Nigeria Nsukka, and the University of Ibadan improved they design.

\section{The UNN model}

The UNN (University of Nigeria, Nsukka) design was constructed by Odigboh and Ahmed (1982) to faithfully simulate the village manual frying operations (Odigboh, 1985). The fryer drives automatically produce continuous flow of well fried garri at $16 \%$ moisture content. An average through-put of $67 \mathrm{~kg}$ of garri per hour has been re -counted for this equipment [16].

\section{The Unibadan Model}

The UNIBADAN model was designed, constructed and manufactured in the University of Ibadan (Igbeka and Akinbolade, 1986). It is a continuous flow fryer which is an upgrading and modification of the UNN model, hence a modified version [17].

\section{The Fabrico Model.}

The modification includes the paddles, the feeding device, and the heat source. The UNIBADAN model isconstructed with a fryer plate, feeding hopper, power transmission devices, and shaft with paddles, pulverizes and an oven on which the fryer rests, The UNN model, Is incorporate with a semi-circular trough open at the top, both ends and a fryer plate. It is positioned at an angle of between 5 and 18 with a length of $2.45 \mathrm{~m}$ and diameter $0.67 \mathrm{~m}$ The. metering device is one of the basic innovations in the model, hoper and the rate of metering is very crucial to the quality of the final product. Another innovation in this model is in the paddles.

Like UNN model, paddles, the main shaft was design with 29 paddles and pulverizes fixed in such a way that they have a conveyor effect at the same time as they press scoop and agitate.
The pulverizes press the sieved cassava mash versus the hot pan surface while the paddles scoop and agitate it [18].

\subsection{Design Innovation}

Recently, innovative design has resultant models such as strategic design, design management and design thinking established speedily. The system of education, policy pertaining innovation and its support have not really measured up with the establishments. Companies that are inexperienced in designmainly SMEs, low-technological companies, plus those not situated in predominantly design business areas - most times lack knowledge of where to find specialized assistance in design. Marketing of design businesses and its influencing powers are generally being affected by the size of the business.

The strength from adopting Innovation brings about solution to some environmental issues as climate change, and some social inequalities. It is a procedure (or a way of thinking) guiding the synthesis of creativity, technology, scientific and commercial restraints towards producing exceptional (and greater) products, services, and communications.

Good design is progressively vital avenue for businesses to grip theirs in global competition. Design has the power to make products and services more attractive to customers and users, so they are able to sell [19].

Innovation means ideas application towards creating fresh solutions. This solution, however, might be a new product, approach or even a new application of an old product or approach. Innovation is creation or acceptance, acclimatization, and exploitation of a important uniqueness in economic and social domains; regeneration and product increment, services, and markets; establishment of fresh production procedures; and production of new systems of management [20].

\subsection{Design Analysis of the Fryer}

Analysis is the progression method of making simpler a compound subject or material into slighter parts in order to acquire a good knowledge of it. The practice has been useful in the learning of mathematics and logical reasoning since before Aristotle in (384-322 B.C.), however analysis as a recognized concept is rather new development. While engineering analysts study necessities, constructions, machineries, schemes and measurements, electrical engineers investigate electronics systems. Systems Life span and down investigated by engineers, who also study various factors merged in the design. [20].

\subsection{Design Analysis of the Mass of the Frying Chamber}

Material - Stainless steel

Density, $\rho-8 \mathrm{~g} / \mathrm{cm}^{3}$

Number -1 unit

Length, $l-900 \mathrm{~mm}=90 \mathrm{~cm}$

Breadth, $b-900 \mathrm{~mm}=90 \mathrm{~cm}$ 
Height (thickness), $h=3 \mathrm{~mm}=0.3 \mathrm{~cm}$

Volume $=l \times b \times h$

Volume $=90 \times 90 \times 0.3=2430 \mathrm{~cm} 3$

$\rho=m$

$/ v$

$m=\rho V=8 \times 2430=19440 \mathrm{~g}=19.44 \mathrm{~kg}$

The mass of the compartment $=19.44 \mathrm{~kg}$

Volume of the Cylinder

Diameter, $d=300 \mathrm{~mm}=30 \mathrm{~cm}$

Height $=900 \mathrm{~mm}=90$

$V=\pi r 2 h(3)$

$=22 / 7 \times 152 \times 90=63642.86 \mathrm{~cm} 3$

However, one-quarter of the volume of the cylinder will be needed to have effective frying i.e. $14 \times 63642.86 \mathrm{~cm} 3=15910.7$ $\mathrm{cm}$

Material - Mild steel

Density $-7.84 \mathrm{~g} / \mathrm{cm}^{3}$

Number -2 units

Length $-670 \mathrm{~mm}=67 \mathrm{~cm}$

Breadth $-50 \mathrm{~mm}=5 \mathrm{~cm}$

Height (thickness) $=3 \mathrm{~mm}=0.3 \mathrm{~cm}$

Volume $=l \times b \times h$

Volume $=67 \times 5 \times 0.3=100.5 \mathrm{~cm} 3$

$\rho=m / V$

$m f=\rho V=7.84 \times 100.5=787.92 \mathrm{~g}=0.788 \mathrm{~kg}$

The mass of the frame $=0.788 \mathrm{~kg}$

Material - Mild steel

Density - $7.84 \mathrm{~g} / \mathrm{cm}^{3}$

Number -2 units

Height $-470 \mathrm{~mm}=47 \mathrm{~cm}$

Diameter $-30 \mathrm{~mm}=3 \mathrm{~cm}$

Volume, $V=\pi r 2 h=227 \times 1.52 \times 47=332.35 \mathrm{~cm} 3$

$\rho=m / V$

$m i=\rho V=7.84 \times 332.85=2605.68 \mathrm{~g}=2.61 \mathrm{~kg}$
The mass of the inner cylinder $=2.61 \mathrm{~kg}$

2.6. Design Analysis of the Outer Cylinder

Material - Mild steel

Density $-7.84 \mathrm{~g} / \mathrm{cm}^{3}$

Number -2 units

Height $-470 \mathrm{~mm}=47 \mathrm{~cm}$

Diameter $-30.4 \mathrm{~mm}=3.04 \mathrm{~cm}$

Volume, $V=\pi r 2 h=227 \times 1.522 \times 47=341.27 \mathrm{~cm} 3$

$\rho=m \quad / V$

$m 0=\rho V=7.84 \times 341.27=2675.6 \mathrm{~g}=2.676 \mathrm{~kg}$

The mass of the outer cylinder $=2.676 \mathrm{~kg}$, Source [21]

\subsection{Applying Computers to Design}

Computers have positively affect engineering like no other. Various engineering areas regularly apply computer for calculation, analysis of information, design and simulation respectively. Computer is used to virtually perform various single tasks within the total design process. When these tasks variously made more proficient, the efficacy of the total process increment becomes pronounced. Computers are specifically located to perform out the areas in design corresponding to the recent mentioned stages of the overall design process. Computers function in the design process via geometric modeling abilities, analysis in engineering controls, programmed testing methods, and automatic drafting [22].

\subsection{Environmentally Sustainable Design}

People that take to designing initiate ideas regarding resource use, consumption manners and the lifespan of products and services. Globally sustainable design otherwise known as green design has the objective of caring for the environment by making sure that the use of resources that are not renewable are minimized, if not minimized entirely in the course of production, and provision of services. The significance is pronounced in architectural work, municipal designing and scheduling. Certain principles of environmentally sustainable design are stated hereunder as reduced- effect resources designing for use of non-toxic, sustainable product or reprocessed materials which need slight or artificial resources (like energy and water) to convey and process, and the use eco-friendly; Resource efficacy: designing industrial processes, services and products which make use of minimum non artificial resources as possible; Superiority and long-lasting: producing durable and improved operational products that are durable, or grow old in a way that have not effect on the value of the product, dropping the effect of creating another one; Re-claim, recycling and renewability: designing products that can be used again, reprocessed or use as compost after first usage. 


\subsection{Designs for Recyclability}

The following guidelines will contribute to speeding up the disassembly process and recovering a larger proportion of system components: Avoid springs, pulleys, and harnesses which complicate the disassembly process. Minimize the use of adhesives and welds between separable components or between incompatible materials. Adhesives introduce contaminants, can detract from quality due to the potential for bond failure, and increase the costs associated with disassembly. If adhesives are required, try to use adhesives that are with the joined materials.

Use snap fits to join components where possible. Snap fits involve an undercut on one part, engaging a molded lip on a mating part to retain an assembly. Snap fits are relatively inexpensive to manufacture and have attractive mechanical properties. Avoid threaded fasteners (screws), if possible, because they increase assembly and disassembly costs. Use alternative bonding methods, such as solvent bonding or ultrasonic bonding. Such methods may be acceptable for bonding parts made from the same material and which will not be separated at end-of-life. Spring clips or speed clips can be an inexpensive and effective way of joining parts and materials. They permit easy assembly and disassembly, and do not introduce contaminants. Illustrated in the assemble drawing [22] below figure1.

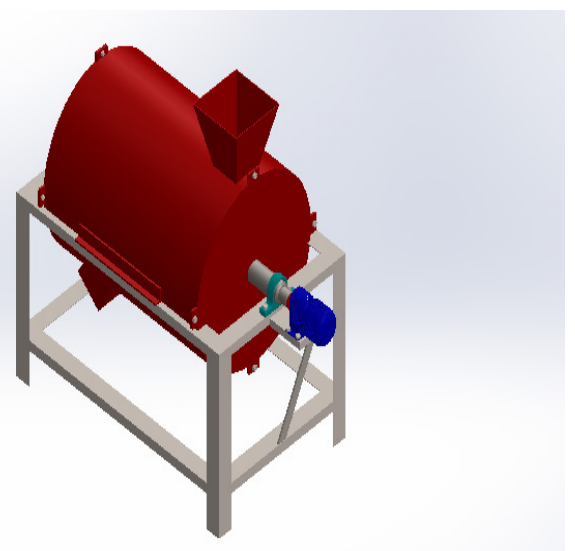

Figure 1: Final Design of Garri frying machine

\subsection{Sustainability}

Successful industrial processes formally have been remarkable by the application simulation technology aimed towards reducing costs, enhancing production and value, minimizing the time it takes to introduce fresh products to the market. Productions that are sustainable includes the incorporation of procedures, taking decision and ecological anxieties of vigorous production system for the growth of the economy, without affecting negatively environment. The application Sustainability to the whole lifespan of a creation is shown in Figure 1. It includes assortment of constituents, removal of those constituents, of portions, gathering approaches, retailing, produce usage, reutilizing, recapture, and removal ensue for success in simulation application to sustainability. Producers are required to concentrate especially on what initially there were not introduced to. Manufacturers will need been concerned with before. [23] Illustrate in Figure 3 and Figure 4.

\section{Sustainability Analysis of Garri Frying Machine}

\subsection{Catalogue of DFE Guidelines}

The guidelines are divided into four principal strategies,

- Design for dematerialization seeks to reduce the required amount of material throughput, as well the corresponding energy requirements, for a product and its associated processes throughout their life cycle.

- Design for detoxification seeks to reduce or eliminate the toxic, hazardous, or otherwise harmful characteristics of a product and its associated processes, including waste streams that may adversely affect humans or the environment Illustrated in Figure 3.

- Design for revalorization seeks to recover, recycle, or otherwise reuse the residual materials and energy that are generated at each stage of the product life- cycle, thus eliminating waste and reducing virgin resource requirements [24].

- Design for Capital Protection and Renewal seeks to ensure the safety, integrity, vitality, productivity, and continuity of the human, natural, and economic resources that are needed to sustain the product life cycle. There is considerable overlap with other DFX disciplines such as Design for Manufacture and Assembly. Indeed, one strength of DFE is its synergy with other design disciplines. For example, reducing design complexity leads to fewer parts, lower assembly costs, and easier disassembly, resulting in reduced energy and material use as well as increased recyclability a principal strategy for improving sustainability is dematerialization, defined as the reduction of material throughput in an economic system. Dematerialization includes a variety of techniques, such as increasing material efficiency in operations; designing products with reduced mass, packaging, or life-cycle energy requirements; replacement of virgin materials with postindustrial or post-consumer wastes; reducing transportation requirements in the supply chain, thus reducing fuel and vehicle utilization; substitution of electronic services for material-intensive services; and substitution of services for products. These techniques are complemented by other DFE practices, such as recovering Value from obsolete or discarded products shown in figure 4

\subsection{Design for Energy and Material Conservation}

Reducing energy and material consumption is the most direct way to improve eco-efficiency, i.e., utilizing fewer resources to deliver equivalent or greater value. Decreasing resource intensity results in higher resource productivity, provides immediate reductions in operating costs, and, thus, is synergistic with business goals. In other words, the quantity and costs of purchased energy and materials are reduced by increasing operating efficiency. 


\section{Component Environmental Impact}

Component

mixer organ

1.

mixer drum

Mixer

mixer drum cover

electric motor

pillow bearing

hex screw am
89

89

62

24

24

2.8

0.040
Carbon

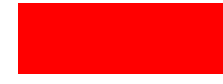

0.037

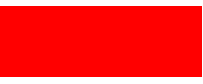

0.037

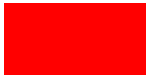

0.206

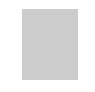

0.081

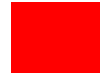

$5.6 \mathrm{E}-3$

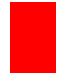

0.514

Energy

Water
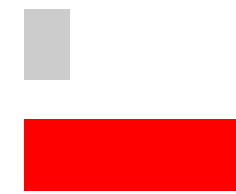

0.510

0.325

0.127

0.171

0.035

$9.8 \mathrm{E}-4$

2.3E-4

1.7E-5
Air

1100

1100

660

260

300

29

0.478

Figure 2: Ten Components Contributing Most to the Four Areas of Environmental Impact

Carbon Footprint

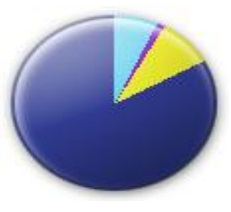

Air Acidification

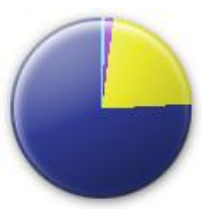

Material: $\quad 1700 \mathrm{~kg} \mathrm{CO}_{2} \mathrm{e}$
Manufacturing: $\quad 180 \mathrm{~kg} \mathrm{CO}_{2} \mathrm{e}$
$\square$ Use:
Transportation: $\quad 25 \mathrm{~kg} \mathrm{CO}_{2} \mathrm{e}$
$\square$ End of Life: $\quad 130 \mathrm{~kg} \mathrm{CO}_{2} \mathrm{e}$

$2000 \mathrm{~kg} \mathrm{CO}_{2}$
Total Energy Consumed
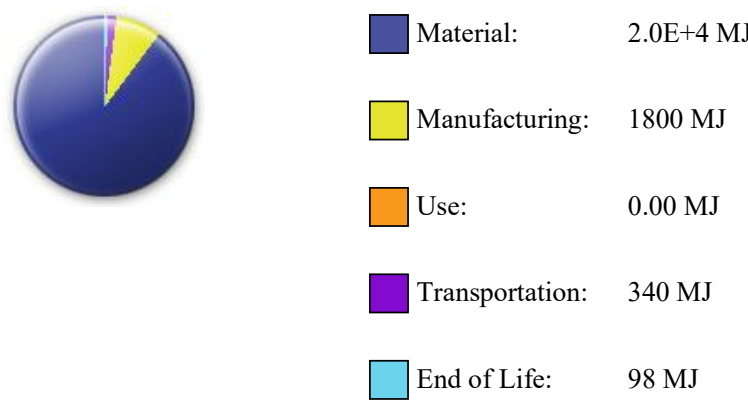

$2.2 \mathrm{E}+4 \mathrm{MJ}$

Water Eutrophication

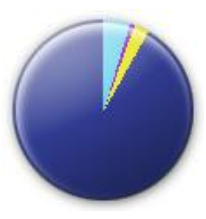

Material:

$3.3 \mathrm{~kg} \mathrm{PO}_{4} \mathrm{e}$

Manufacturing: $\quad 0.096 \mathrm{~kg} \mathrm{PO}_{4} \mathrm{e}$

Use: $\quad 0.00 \mathrm{~kg} \mathrm{PO}_{4} \mathrm{e}$

Transportation: $\quad 0.029 \mathrm{~kg} \mathrm{PO}_{4} \mathrm{e}$

End of Life: $\quad 0.167 \mathrm{~kg} \mathrm{PO}_{4} \mathrm{e}$

$11 \mathrm{~kg} \mathrm{SO}_{2} \mathrm{e}$

$$
3.6 \mathrm{~kg} \mathrm{PO}_{4} \mathrm{e}
$$

Figure 3 Environmental Impact (calculated using CML impact assessment methodology) 
Moreover, energy reduces overall material consumption in the supply chain, since generating energy requires some type of fuel and/or equipment. Although energy management is often pursued as a separate program, energy and material resource conservation should, ideally, go hand-in-hand. Finally, energy conservation that reduces fossil fuel use will also reduce greenhouse gas emissions.

\subsection{Life-Cycle Resource Intensity Reduction}

DFE needs to consider the full life cycle of a product, including all of the processes involved in sourcing, production, distribution, use, and recovery of the product. Thus, the investigation of opportunities for energy and material conservation should consider both supplier and customer processes. Depending on geographic locations and type of facilities, certain companies in the supply chain may have much better opportunities than others for energy and material conservation. The following types of opportunities should be explored, shown in Figure 2.

\section{Baseline}

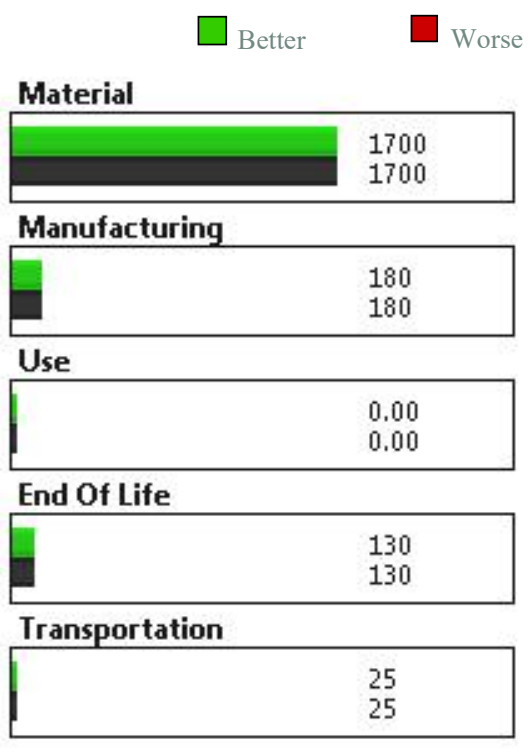

\section{Air Acidification - Comparison}

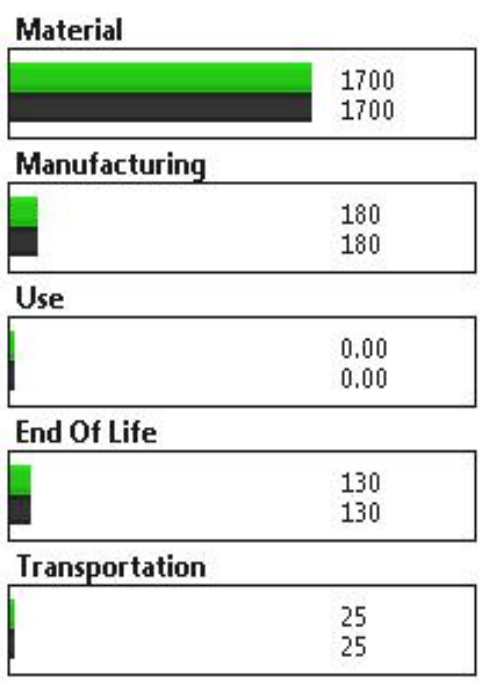

Water Eutrophication - Comparison

\begin{tabular}{|l|}
\hline Material \\
\hline \multicolumn{1}{|l|}{} \\
\hline Manufacturing \\
\hline \\
\hline \\
\hline Use \\
\hline
\end{tabular}

\section{Material Financial Impact Comparison}

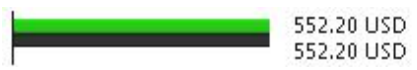

Figure 4: Environmental Impact Comparison

Many companies have begun to examine the environmental practices of their suppliers and encourage greater energy and material efficiency. This can reduce the life-cycle footprint of their own products and potentially lower their costs. The most prominent example is Wal-Mart, which has developed sustainability scorecards for packaging and energy use and is requesting environmental performance improvements from all of its suppliers.

\subsection{Reduce the Operational Resource Footprint}

Companies have found a great deal of "low-hanging fruit" by tightening up energy management practices, e.g., heating, cooling, and lighting systems, and materials management practices, e.g., maintenance, inventory, and waste management. Newer facilities are being designed with recycled materials and advanced energysaving features, as interest in "green building" has mushroomed. But the largest gains in resource conservation come from redesigning production processes to reduce throughput requirements and Install more efficient equipment. Example: From 2005 to 2007, General Electric (GE) conducted a "Lean and Energy" initiative that identified over $\$ 100$ million in potential energy savings through over 200 "energy treasure hunts" at GE facilities worldwide. This effort resulted in 5,000 related kaizen projects, most of which are funded and in various stages of implementation. GE was able to reduce greenhouse gas emissions by 250,000 metric tons and realized $\$ 70$ million in energy cost savings from implemented projects.

\section{Sustainability Analysis in Garri Frying Machine Manufacturing in Nigeria: Design Innovation}

In Nigeria, it appears that those agriculturists are not rich as to compare with other people in other sectors of the economy. That 
is to say that their living standard is so low that acquiring facilities is a major problem that among others affect their agricultural development.

Studies confirmed that the little processing equipment that are small are small efficiency. This has actually affect negatively the production rate of farmers.

Productivity in Agriculture equals the ratio of outputs to inputs. Whereas discrete goods are typically stated using weight, various densities of them make difficult determining total agricultural output. As a result, measuring the output is dependent on market worth of last output, which omits middle crops use in meat industry as corn feed. The output worth is compared with yield from diverse categories of inputs labour and land. These are productivity partial actions. There is transformation basically on how we think of management of manufacturing as the four concepts develops. United States manufacturers are not ignorant of the fact that we need manufacturing theory that is recent. We are aware that mending ancient theories are not workable and in furtherance of it will really throw us backwards. Actually, these ideas offer us the basis for the requisite theory.

Immediately we describe manufacturing as the procedure that changes belongings for the satisfaction of the economy, obviously, production continues even when the produce originate from the company. Physical circulation of products and services which are portion of the producing procedure are combined with it, synchronized it, achieved organized with it. It is even now broadly documented that overhauling the produce is most important thought in the course of design and production. Customarily, manufacturing commerce have been prearranged "in series," with tasks as manufacturing, engineering, and advertising as sequential stages. Nowadays, that system is frequently supplemented by a similar crew body (Procter \& Gamble's product management teams are a well-known example), which gives several tasks together as of the commencement of a novel produce or procedure scheme. If industrial activities are to be system, nevertheless, every single resolution in a manufacturing business turn out to be a manufacturing decision. Every single decision be duty-bound to meeting with the manufacturing's desires and requirements, and sequentially ought to exploit the powers and aptitudes of a company's exact engineering system. Undeniably, we have power to move ahead and involve executives all over the company to go round the factory projects during the course of their careers. Therefore, every single manufacturing boss ought to acquire as well as run-through a training that incorporates engineering, organization of people, as well as business economics into the manufacturing process. Moderately a small number of manufacturers presently work on that unknowingly. Hitherto such training has not been systematized as well as not imparted in engineering.

God so generous to Nigeria, nonetheless Nigerians have not been benevolent to Nigeria. Our country has been extraordinarily preferential vested upon with natural, mineral, and human resources. And the fertility of the lands is such that planting one finger will grow to becoming a human being, but we lack leadership skills [25].

It is as a result that of the above that this work theme was resultant and the benefits are as ensuing [26].

Cost Effective: it has low as well as inexpensive cost within the wealthy. Besides, it needs slight or no recurrent looking after.

- Increase in Productivity- productivity increment brings about affluence increase of a Nation. Productivity of garri frying machine drive maximally in bringing about extent of increase in productivity level of a Nation which will rise worth totaling to GDP.

- Poverty Reduction and Job Creation: Its assistance in job creation is enormous as seen it its necessitating reduction in the migration between rural-urban.

- Usage and Observation by Local Fabricators. Ever since the machine is invented locally, the procedure drives local producers to modernize or improve in their construction. Therefore, cumulative the health rural people.

- Decrease in Joblessness. The decrease of joblessness are those machine fabricators as well as those using the machine will be the recipients.

- Inspire Direct as well as Indirect Investment, It drive hastily growth in industrial creation for garri manufacturing as well as further cassava processing projects. It will likewise intensify speedy growth and development of the Nation's economy.

- Economic Improvement and Industrial development. It will help in economic improvement and industrial development for the reason that it necessitates the formation of fresh asset culture, affluence establishment as well as enlarged economic plus social welfare. Entirely, these brings about enhanced application of cassava beforehand to avoid spoiled owing to small shelf life [27].

\section{Conclusion/Recommendation}

In accurately united method, DFE must be well-adjusted in contrast to other cost as well as superiority factors that sway design choices. The spot of an efficacious group is the capacity to revolutionize underneath stress, somewhat than conceding product excellence. [28] A "win-win" result is the bringing about of ecologically advantageous improvements that likewise advance the charge in addition to functionality of the invention as soon as is observed as portion of the total system [29]. If at all possible, lone design invention might donate to accomplishing quite a lot of dissimilar sorts of objectives. For instance, decreasing the quantity of a produce be able to cause in 1 energy in addition to measureable decrease, which gives to resource protection, as well as noxious waste release reduction, which gives to healthiness as well as security. Creation trade- off ideas is the greatest perplexing portion of the course for the reason that of the prerequisite to at once think through so numerous dissimilar standards. Base on this conversation the succeeding policy stay essential, hard work ought to be done to accept as well as disseminate the design-DFX, DFA, DFE illustrated in Figure1- 4 above ETC particularly for the profits of menfolk who create up 
a pronounced proportion of the Nation's inhabitants. If, the usage of machine design innovations embraced, the difficulty in garri as well as supplementary agricultural handing out Tools will be lessened besides hunger as well as poverty will be exterminated.

\section{Conflict of Interest}

We declare no conflict of interest associated with this manuscript.

\section{Acknowledgment}

This Research was Sponsored by Tertiary Education Trust Fund(TETFUND) No6 Zambezi Cresent. off Agniyi Ironsi Street, Maitama, Abuja, Nigeria Tel: 07098818818.

\section{References}

[1] Akinyemi, J. O. and Akinlua. (1999). Design, Construction and Testing of Cassava Grater. International Journal of Tropical Agriculture. 17(1-4); pp103-108.

[2] Olukunle, O. J. and Ademosun, O. C. (2006). Development of a double action self -fed cassava peeling machine. Journal of food, Agriculture and Environment (JFAE), Accepted for publication

[3] Olukunle O. J. and Oguntunde P. G. (2008). Analysis of Peeling Pattern in an Automated Cassava Peeling System. Nigerian Journal of Technological DevelopmentVol.6 No. 1\&2 41-52

[4] Olukunle O. J. and Atere, A. O. (2009). Developments in Cassava Peeling Mechanisation. Proceedings of the International Conference the Nigerian Institution of Agricultural Engineers/West African Society of Engineers, held at Obafemi Awolowo University, Ile -Ife

[5] Odigboh, E. U. (1983). Cassava Production, Processing and Utilization. In: Chan Jnr., H. T. (ed), Handbook of Tropical Foods. Marcel Decker Publisher, Inc.; 270, Madison Avenue, New York; pp145 200

[6] Igbeka, J. C. (1995). Recent Developments in Cassava Frying Operation and Equipment used for Garri Production in Nigeria. ORSTOM: pp583-590

[7] Jackson, A. T. and Lamb, J. (1981). Calculations in Food and Chemical Engineering (Theory, Worked Examples and Problems). Mac Millan press Ltd, London. pp209.

[8] Odigboh, E. U. and Ahmed, S. F. (1982). Design of the Continuous Process Garri Frying Machine. Proceedings of the Nigeria Society of Engineers; 6(2); $65-75$

[9] Gbasouzor Austin Ikechukwu, A. I. V. Maduabum (2012 Improved Mechanized Garri Frying Technology Sustainable Economic Development in Nigeria by proceeding $s$ of international multiconference of Engineers and computer scientists

[10] Chime .O Thompson, Inyiama Fidelis Chidozie and Okonkwo Gloria Ngozi (2016) Design Innovation, Modelling and Simulation: Sustainability of Analysis of Bench Reactor for Kinectic Study of Hydro Carbon Removal Using Land Farming published by International Journal of Engineering Technology and Computer Research (IJETCR) www.ijetcr.org

[11] Asheen Phansey, "Biomimicry," Berkshire Encyclopedia of Sustainability: The Business of Sustainability (New York: Berkshire Publishing Group, 2009), p. 37

[12] Michael Beaney (Summer 2012).Anlysis. The Inford Encyclopedia of Philosophy.Michael Beey Retrieved 23 May 2012.

[13] Our Common Future, Report of the World Commission on Environment and Development, World Commission on Environment and Development, 1987. Published as Annex to General Assembly document A/42/427, Development and International Co-operation: Environment August 2, 1987.

[14] R. Chime, et al (2017) Improving Productivity In Hollow Impeller Palm Nut Cracking Machine Manufacturing In Nigeria published by Internal journal of Engineering technology and Computer Research(IJETCR)WWW.ijetcr.org March/April Edition

[15] Okechuku (2012) Improved Mechanized Garri Frying Technology for Sustainable Economic Development in Nigeria Proceedings of the International Multi Conference of Engineers and Computer Scientists 2012 Vol II, IMECS 2012, March 14 - 16, 2012, Hong Kong

[16] J.C. Igbeka, mechanization for cassava processing", Journal of Agricultural Mechanization in Asia, Africa and Latin America (AMA), 22(1), pp. 45-50, 1972 M. Jory and D. Griffon, "Selective

[17] E.U. Odigboh. (1985) "Prototype Machines for small- and medium-scale harvesting and processing of cassava, Yaounde, Cameroun. pp $323-338$,
[18] R .O.Chime, et al (2017) Improving Productivity In Hollow Impeller Palm Nut Cracking Machine Manufacturing In Nigeria published by Internal journal of Engineering technology and Computer

[19] Charles, M. Manufacturing Simulation; The need for Standard Methodologies, Model, and Data Interfaces, 2009.

[20] J.A.Onuigbo and R.O.Chime (2018) Innovation in Feed Mixing Machine: Design for Manufacturing in Industry by World Journal of Engineering Research and Technology www.wjert.

[21] B.O. Akinnuli, C.O. Osueke, P.P. Ikubanni O.O. Agboola and A.A. Adediran()2015Design Concepts Towards Electric Powered Garri Frying Machine by International Journal of Scientific \& Engineering Research, Volume 6, Issue 5, May-2015 1043 ISSN 2229-5518

[22] The Danish government's 2007 white paper on design,

[23] Design Issues," in Tool and Manufacturing Engineers Handbook, Dearborn, Mich., 1992

[24] Joseph Fiksel: Design for Environment: A Guide to Sustainable Product Development, Second Edition. Design Rules and Guidelines, Chapter (McGraw-Hill Professional, 2009 1996), Access Engineering

[25] R.O.Chime(2006)leadership Training published by Coal City Engineer The Nigerian Society of Engineer Enugu State Branch

[26] J.A.Onuigbo and R.O.Chime (2018) Innovation in Feed Mixing Machine: Design for Manufacturing in Industry by World Journal of Engineering Research and Technology www.wjert

[27] R .O.Chime et al (2017) Improving Productivity In Hollow Impeller Palm Nut Cracking Machine Manufacturing In Nigeria published by Internal journal of Engineering technology and Computer Research(IJETCR)WWW.ijetcr.org March/April Edition

[28] Peter F. Drucker (1999) The Emerging Theory Manufacturing, MayJune 1990 issue of Harvard Business Review.

[29] Bulent Sezen,Sibel Yildiz Cankaya (2013) Effects of green manufacturing and eco-innovation on sustainability performance Published by Elsevier Ltd. Selection and peer-review under responsibility of the International Strategic Management Conference www.sciencedirect.com

[30] The Emerging Theory of Manufacturing Peter F. Drucker from the MayJune 1990 Issue

[31] Design Issues," in Tool and Manufacturing Engineers Handbook, Dearborn, Mich., 1992

[32] Douglas Harper (2001-2012)."Analysis(N)" Online. Etymology Dictionary . Douglas Harper. Retrieved 23 May 2012. 